Ks. Roman SZMUR£O

(Warszawa, UKSW)

\title{
ELEMENTY STRUKTURY HIERARCHICZNEJ ORAZ WARUNKÓW SPOŁECZNO-EKONOMICZNYCH KLASZTORÓW MANICHEJSKICH W AZJI CENTRALNEJ W ŚWIETLE ANALIZY WYBRANYCH DOKUMENTÓW Z TURFAN
}

Źródła manichejskie, odkryte w XX wieku w Egipcie (Medinet Madi, Kellis), jak i w Niemczech (Codex Manichaicus Coloniensis), dostarczają informacji o życiu ascetycznym manichejczyków, które przybierało formę monastyczną ${ }^{1}$. Interpretacja Kodeksu Kolońskiego nasuwa przypuszczenia, iż wspólnota tzw. Elkazaitów, w której wychowywał się Mani, posiadała strukturę, którą dziś możemy określić jako monastyczną ${ }^{2}$. Mani po opuszczeniu wspólnoty Elkazaitów miał rzekomo udać się do Indii, gdzie zapoznał się z funkcjonowaniem buddyjskich wspólnot monastycznych. Doświadczenie to wpłynęło na jego koncepcję organizacji struktur monastycznych. W późniejszym okresie ascetyczne wspólnoty manichejskie rozkwitły szczególnie w Turkiestanie i dzisiejszych Chinach. O ich istnieniu i funkcjonowaniu świadczą odnalezione w Turfan dwa pisma. Na podstawie ich częściowej analizy chciałbym pokrótce przybliżyć role społeczną i ekonomiczną ascetycznych wspólnot manichejskich.

I. WYBRANE DOKUMENTY Z TURFAN JAKO ŹRÓDŁO DO POZNANIA SPOŁECZNEJ I EKONOMICZNEJ ROLI MANICHEJSKICH WSPOLNOT MONASTYCZNYCH

Wśród materiału źródłowego należy wyróżnić „Kompendium Doktryn i Stylów Maniego, Buddy Swiatła" (Mo-ni kuang-fo chiao-fa yi-lueh). Tekst ten powstał, jak się uważa, w jednym z języków Azji Centralnej, prawdopo-

\footnotetext{
${ }^{1}$ Por. L. Koenen, Manichäische Mission und Klöster in Ägypten, w: Das römisch-bysantinische Ägypten. Akten des internationalen Symposions (26.-30. September 1978 in Trier), Aegyptiaca Treverensia 2, Mainz am Rhein 1983, 93-108; zob. także I. Gardner, ,He has gone to the monastery", w: R.E. Emmerick - W. Sundermann - P. Zieme, Studia Manichaica (IV Internationaler Kongres, Berlin, 14-18 Juli 1997), Berlin 2000, 247-257.

${ }^{2}$ Por. S.N.C. Lieu, Precept and Practise manichean monasticism, JTS 32 (1981) 157-158. W dalszej części opracowania artykuł S.N. Lieu oznaczymy skrótem: Precept; por. także Koenen, Manichäische Mission, s. 94-95.
} 
dobnie w irańskim. Ale istnieją także hipotezy, iż mógł zostać napisany w języku sogdiańskim, środkowoperskim, czy też partyjskim. Tekst zostal przetlumaczony na język chiński przez urzędników dworu cesarskiego w 731 roku $^{3}$. Historia publikacji tego Kompendium jest jednak skomplikowana i złożona. W czasie odkrycia dzieło to zostało rozdzielone i zachowało się w dwóch częściach, końcową zaś część tekstu przetłumaczył i opublikował w 1913 r. Francuz Paul Pelliot. Od jego imienia tę część nazwano „Fragmentem Pelliot"4. Główna część tekstu została odnaleziona wśród zwojów z Tung Huang i opublikowana przez G. Halouna i W.B. Henninga w 1952 rokus. Ci dwaj uczeni nie wzięli jednak pod uwagę tłumaczenia Pelliota; nie dokonali zatem kompilacji obu fragmentów. Stąd też wielu nadal traktuje „Fragment Pelliota" jako odrębne pismo, oddzielne od tekstu Halouna-Henninga, a zatem nie wchodzace w skład Kompendium ${ }^{6}$.

W latach pięćdziesiątych, wśród pism z Turfan, chińscy archeolodzy odkryli dokument w języku ujgurskim, który dość dokładnie odsłania struktury życia monastycznego wspólnot manichejskich w Królestwie Ujgurów: nazwano go Dokumentem z Qočo. Na jego podstawie uczeni mogli porównać organizację i funkcjonowanie wspólnot monastycznych $z$ treściami zawartymi w Kompendium $^{7}$. Zauważyli ponadto, że wiele przykazań z Kompendium nie straciło swojej aktualności. Pomimo, iż pierwsze zdjęcia tekstu zrobiono podczas ekspedycji, to właściwie do roku 1975 nie został on opublikowany. W tymże roku Niemiec Peter Zieme przetłumaczył i wydal dające się odczytać części dokumentu.

Dokument (Tsung $8782 \mathrm{~T}$ ) ma rozmiary 270 na $29,5 \mathrm{~cm}$ i zawiera 125 wersów pisma: zarówno początek jak i koniec tekstu uległy zniszczeniu. Zdaniem P. Zieme, niektóre partie zwoju zostały szczególnie zniszczone. Widnieje na nich jedenaście razy pieczęć Kancelarii Królestwa Ujgurów, która pokryła cztery wersy $z$ tekstu pisma ${ }^{9}$. Jak zauważa S.N. Lieu, dokument ten nie jest regułą jakiegoś klasztoru, ale królewskim statutem sugerującym pewne rozwiązania $w$ relacjach pomiędzy grupą klasztorów a wspólnotą świeckich w sprawach społecznych i ekonomicznych, jak również w kwestii rozwiązywania problemów występujących wewnątrz wspólnot ${ }^{10}$. Wspomniane są tam trzy

${ }^{3}$ Por. W. Sundermann, Namen von Göttern, Dämonen und Menschen in iranischen Versiones des manichäisches Mythos, "Altorientalische Forschungen” 6 (1979) 113-115.

${ }^{4}$ Por. Don 4502, coll. Pelliot, inv. 3884 w Bibliothèque Nationale w Paryżu, za Precept, s. 161.

5 Por. G. Haloun - W.B. Henning, The Compendium of the Doctrines and Styles of the Teaching of Mani the Buddha of Light, „Asia Maior” N.S. 3 (1952) 184-212. W dalszej częsci dzieło występuje pod skrótem: The Compendium.

${ }^{6}$ Por. Precept, s. 161.

7 Por. tamże, s. 164.

${ }^{8}$ Por. P. Zieme, Ein uigurischer Text über die Wirtschaft manichäischer Klöster im Uigurischen Reich, w: Researches in Altaic Languages, ed. L. Ligetti , Budapest 1975, 331-338.

${ }^{9}$ Por. tamże, s. 336.

${ }^{10}$ Por. Precept, s. 164. 
klasztory, które znajdowały się w Turfan, Yar i Solmi. Z tekstu wynika, iż szczególną rolę pelnił wśród nich klasztor w stolicy kraju, czyli Turfan ${ }^{11}$.

Fakt, iż kancelaria Królestwa przygotowała takowy statut, może świadczyć o roli, jaką w Państwie Ujgurów odgrywały manichejskie wspólnoty monastyczne. Analiza poszczególnych punktów tego tekstu prowadzi do wniosku, iż wspólnoty klasztorne pełniły znaczącą rolę społeczną i ekonomiczną, a także misyjną w Królestwie. Postaramy się teraz przybliżyć wyniki analizy prezentowanych tekstów, przy czym pragniemy nadmienić, iż do analizy wykorzystaliśmy je w thumaczeniach.

\section{ELEMENTY STRUKTURY. HIERARCHICZNEJ MANICHEJSKICH WSPOLNOT MONASTYCZNYCH}

Analiza Kompendium pozwala nam na wstępie wyróżnić stopnie hierarchiczne w Kościele manichejskim. Stanowią one podstawę do zrozumienia poszczególnych elementów struktury hierarchicznej we wspólnotach monastycznych. Jak zauważa S.N. Lieu, są one podobne do wyodrębnionych przez św. Augustyna z Hippony stopni w Kościele manichejskim w Afryce Północ$n^{12}{ }^{12}$. Możemy więc wyodrębnić pięć stopni hierarchii manichejskiej: 1 . Dwunastu Mu-she (pers. mozak, łac. magister) czyli „nauczyciel Drogi”; 2. Siedemdziesięciu dwóch Sa-po-sê (pers. ispasag, łac. episçopus, aftadan) czyli „Podtrzymujący Prawo"; 3. Trzystu sześćdziesięciu Mo-hsi-hsi-te (pers. mahistag, łac. presbyter) czyli „Główny Sali Prawa”. 4. A-lo-huan (per. ardawan, lac. electi czyli „wszyscy nieskazitelnie dobrzy ludzie”). 5. Nou-sha-an (łac. auditores to znaczy w thumaczeniu ,Wszyscy czyści i wierni słuchacze") ${ }^{13}$. Jak widać $\mathrm{z}$ powyższego, w klasztorach manichejskich wspomniane są funkcje: episcopus, electi, auditores ${ }^{14}$.

Analiza Kompendium dostarcza nam również informacji, iż na czele wspólnot stało trzech tzw. Ch'üan-chien (dosł. wybrać lub ustanowić, czyli można by nazwać ich „wybranymi” czyli Electi) ${ }^{15}$. Pierwszy z nich $A$-fu-in-sa (śr pers. afrinsar) - co można oddać jako „mistrz chóru”; był on prawdopodobnie odpowiedzialny za sprawy związane $\mathrm{z}$ religią i kultem. Drugi - Hu-lu-han (śr. pers. xrohxwan). Thumaczenie tej nazwy brzmi: „ten, kto uczy drogi”; głównym jego zadaniem był kontakt $\mathrm{z}$ podwładnymi: udzielał on pochwał za pełnione dobro, a karcił za zło. Trzecim przełożonym był Ngo-huan-chien s $\hat{e}$ -

11 Por. tamże, s. 165.

12 Por. tamze, s. 161.

${ }^{13}$ Por. The Compendium, s. 195.

${ }_{14}$ Por. tamze, s. 187, 194, 199.

15 Por. Ed. Chavannes - P. Pelliot, Un traité retrouvé en Chine (Deuxieme partie), „Journal Asiatique" 11 (1913) 107-116. 
po- sê (śr. perski ruwanagan ispasig). Urząd ten można przetłumaczyć jako „kontroler miesięcy"; do jego obowiązków należała kontrola nad otrzymywanymi na rzecz wspólnot ofiarami. Wszyscy członkowie wspólnot winni być posłuszni tym trzem przełożonym ${ }^{16}$. W Kompendium także znajdujemy imiona własne pewnych osób (Miklasia), które, jak uważa Henning, mogły pełnić funkcje przełożonego we wspólnotach monastycznych: określił ich terminem $\operatorname{archegos}^{17}$. Dokument nie precyzuje zakresu jego kompetencji. Wspomina jedynie, iż zabierał stanowczo głos, gdy członkowie wspólnoty naruszali przepisy doktryny manichejskiej, zajmując się pracą manualną czy też zażywając kąpieli $^{18}$.

Wspomniany natomiast Dokument z Turfan prezentuje urzędy „gospodarcze" we wspólnotach monastycznych. Początek wspomnianego tekstu zawiera przepisy regulujące przechowywanie wszelkich dóbr materialnych, jak i przychodów pieniężnych we wspólnotach. Na tym tle wymienia urzędników, którym wolno było wchodzić do spichlerzy i magazynów, gdzie przechowywano otrzymane czy też wypracowane dobra materialne. Dokument wymienia następujące funkcje: is ayyuci, mozak, ilimga, tutu ${ }^{19}$. Nazwy urzędów występują w tekście blisko wymienionych posiadłości ziemskich, należących do wspólnot. Prawdopodobnie mieli nimi zawiadywać poszczególni członkowie hierarchii. $\mathrm{Na}$ podstawie tego pisma trudno jest rozróżnić zakres kompetencji pomiędzy wspomnianymi urzędnikami ekonomicznymi. Jak zauważa S.N. Lieu, zarówno is ayyuci, jak również mozak, a także aftadan, czyli także magister i episcopus, winni okazywać troskę o dobra ziemskie wspólnot ${ }^{20}$, choć szczególna rola w zarządzaniu dobrami przysługiwała is ayyuci. Do jego szczegółowych kompetencji należała także kontrola nad osobami odpowiedzialnymi za rozliczenia przychodów i rozchodów wspólnot. Zadaniem jego była również kontrola jakości przygotowywanych i podawanych potraw w refektarzu mnichów ${ }^{21}$.

Analiza Kompendium i Dokumentu z Qočo pozwala nam wyróżnić stopnie w hierarchii tzw. Kościoła manichejskiego, jak również stanowiska w monastycznych wspólnotach manichejskich. Prócz archegosa wyróżnialy się stanowiska związane z ekonomicznym zarządzaniem wspólnotami. Analiza wspomnianych dokumentów pozwala nam dostrzec relacje ekonomiczne wspólnot monastycznych ze światem zewnętrznym oraz rolę, jaką ogrywały w Państwie Ujgurów.

${ }^{16}$ Por. The Compendium, s. 195; zob, też Chavannes - Pelliot, Un traité retrouvé en Chine, s. 108-114; F. Decret, Mani e la tradition manichéenne, Paris 1974, 113-116.

${ }_{17}$ Por. The Compendium, s. 198, 201; W.B. Henning, Neue Materialen zur Geschichte des Manichäismus, „Zeitschrift der Deutschen Morgenländischen Gesselschaft” 96 (1936) 16-18.

18 Por. Precept, s. 170.

19 Por. tamie, s. 165.

20 Por. Zieme, Ein uigurisher, s. 332, wiersze 92-94.

21 Por. Precept, s. 165 i 169. 


\section{ELEMENTY STRUKTURY SPOŁECZNO-EKONOMICZNEJ WSPOLNOT MONASTYCZNYCH}

Piąty artykuł Kompendium jest opatrzony tytułem „O budynkach w klasztorze". Wymienia on pięć rodzajów pomieszczeń, które służyły członkom wspólnot: 1. Jeden pokój dla pism i obrazów, 2. Jeden pokój dla postu i kazań, 3. Jeden pokój dla kultu i spowiedzi, 4. Jeden pokój dla nauczania religijnego, 5. Jeden pokój dla chorych mnichów ${ }^{22}$. Według rozporządzenia zawartego w Kompendium, mnisi powinni żyć w tych pomieszczeniach we wspólnocie, praktykując gorliwie dobre uczynki. Dalej dokument wyraźnie stwierdza, iż mnisi nie powinni budować cel jednoosobowych, ani kuchni dla poszczególnych grup mnichów. Należałoby wnioskować, iż członkowie wspólnoty, niezależnie od pozycji zajmowanej w hierarchii, spożywali razem posiłek ${ }^{23}$.

Wspomina również o jednym ze sposobów zdobywania pożywienia czy też zapewnienia środków utrzymania dla wspólnoty; sposobem tym było przyjmowanie jałmużny. Kompendium nakazuje, aby mnisi przyjmowali jałmużnę $\mathrm{z}$ godnością, nie precyzując przy tym na czym owo „przyjmowanie z godnością" miało polegać. Być może autor chcial zaakcentować, aby mnisi nie chodzili prosić o jałmużnę, gdy posiadają dobra, które im do klasztoru przyniesiono. Prawdopodobnie ostrzegal przed zbytnią zachłannością na dobra materialne $\mathrm{e}^{24}$.

Dokument z Qočo, który powstał dwa wieki później, przedstawia nieco inaczej kwestie utrzymania wspólnot: wspomina o fakcie posiadania przez wspólnoty monastyczne ziem, na których uprawiano między innymi winną latorośl. Taki rodzaj upraw może wydać się dziwny ze względu na doktrynalny zakaz spożywania wina przez manichejczyków: mogli jedynie spożywać sok $\mathrm{z}$ winogron, który nie uległ fermentacji ${ }^{25}$.

Wspomniany dokument pośrednio informuje również o tym, iż mnisi manichejscy mogli prawdopodobnie w klasztorach hodować także zwierzęta. Takie twierdzenie należałoby uznać za zasadne, gdyby termin sirmunki i quanci przetłumaczyć jako „opiekun stada” „strzegący gęsi”"26. Informacja o hodowli zwierząt stoi w sprzeczności z prawem zawartym w piątym artykule Kompendium, które stanowczo zabrania takiej praktyki ${ }^{27}$. Także nadmierna troska o owocne zarządzanie uprawami w celu podniesienia jakości plonów mogłaby

${ }^{22}$ Por. The Compendium, s. 205; Precept, s. 161-162.

${ }^{23}$ Por. The Compendium, s. 205-206.

24 Por. Precept, s. 162 i 167.

${ }^{25}$ Por. R. Boyce, A reader in Manichean Middle Persian and Parthian Text with Notes (ser. II 9; Textes et memoires), Teheran - Liège - Leiden 1977; zob. także, Precept, s. 168.

${ }^{26}$ Por. Precept, s. 170.

27 Por. The Compendium, s. 207; także A. Vööbus, History of Ascetism in the Syrian Orient I, CSCO 184, Subsidia 14, Louvain 1958, 119. 
Świadczyć o przywiązaniu do dóbr materialnych. Świadczyłoby to o stopniowym rozluźnianiu dyscypliny monastycznej i odchodzeniu od pierwotnego ideału.

Kolejnym dowodem na odchodzenie od manichejskiego ideału ubóstwa była uwaga, jaką mnisi zwracali na jakość i obfitość klasztornego stołu. Jak zauważa S. Lieu, mieszkańcy wspólnot znajdujących się w Królestwie Ujgurów kładli szczególny nacisk na jakość potraw. Za dostawy na klasztorny stół oraz przygotowanie potraw był odpowiedziainy is ayuci. Za wszelkie zaniedbania ponosił surowe konsekwencje. Podobnie winni zostać ukarani kucharze, którzy źle lub niestarannie przygotowali posiłek ${ }^{28}$.

Należy dostrzec także różnicę w tekście obydwu dokumentów odnośnie posługiwania we wspólnotach. Kompendium dość stanowczo wskazywało, iż kapłani ze wspólnoty winni być obsługiwani jedynie przez auditores ${ }^{29}$. Nie wolno im było kórzystać z usług nikogo innego: żadnych usługujących. Natomiast w Dokumencie $z$ Qočo zauważamy, iż kapłani mogli mieć usługujących obojga płci. Na określenie „sługi” używano terminu aspasi co, jak zauważył S. Lieu, oznaczało nie tylko zwyczajnego służącego, ale także „wierzącego niższej rangi albo brata laika" ${ }^{30}$. Prócz posługi wyżej wymienionych klasztor korzystał także z usług pracowników spoza wspólnoty takich jak: piekarze, krawcy, stolarze, tkacze. Pismo wspomina także, iż chorzy kapłani wyższej rangą korzystali z opieki medycznej spoza klasztoru ${ }^{31}$.

Powyższe dwa dokumenty przedstawiają opisowo poszczególne elementy struktury hierarchicznej, jak również funkcjonowania monastycznych wspólnot manichejskich w Królestwie Ujgurów. Teksty świadczą o roli, jaką odgrywały tego typu wspólnoty w strukturze Państwa. Jednocześnie pozwalają zauważyć stopniową ewolucję przepisów monastycznych jak również sposobu ich obserwancji.

\footnotetext{
${ }^{28}$ Por. Zieme, Ein uigurisher, s. 335.

${ }^{29}$ Por. Henning, Neue Materialen zur Geschichte des Manichäismus, s. 16-18.

${ }^{30}$ Por. Precept, s. 171.

31 Por. tamże, s. 171.
} 


\section{GLI ELEMENTI DELLA STRUTTURA GERARCHICA ED ECONOMICA DEI MONASTERI MANICHEI IN ASIA CENTRALE NELLA LUCE DEI DOCUMENTI DI TURFAN}

(Sommario)

Le fonti manichee scoperte nel XX secolo nell'Egitto (Medinet Madi, Kellis) trasmettono le informazioni sulla vita ascetica dei manichei, che si sviluppava in forma monastica. Più tardi le comunità ascetiche manichee fiorirono specialmente in Turchestan e Cina. Ne danno testimonianza due scritti: Compendio della dottrina e della regola insegnante di Mani, Buddha della Luce e cosi detto Documento di Qočo. I documenti descrivono gli elementi della struttura gerarchica e il modo in quale funzionavano le communità manichee nel Regno degli Ujguri. Le communità facevano una parte importante nella struttura dello stato. Si puó anche accorgere l'evoluzione della osservanza dei comandamenti monastici. 